\title{
Peningkatan Kesehatan Masyarakat Melalui Sosialisasi Penggunaan Tanaman Obat Keluarga (Toga) Di Lingkungan Bandung
}

\section{Improving Community Health Through Socialization Of The Use Of Medicinal Plants In The Family (Toga) In Lingkungan Bandung}

\author{
${ }^{1}$ Enik Suhariyanti, ${ }^{2}$ Rizka Amalia, ${ }^{3}$ Muta Aliva \\ ${ }^{1)}$ Program Studi D3 Ilmu Keperawatan, Fakultas Ilmu Kesehatan Universitas Muhammadiyah Magelang \\ ${ }^{2)}$ Program Studi S1 Farmasi, Fakultas Ilmu Kesehatan Universitas Muhammadiyah Magelang \\ ${ }^{3)}$ Program Studi S1 Ilmu Keperawatan, Fakultas Ilmu Kesehatan Universitas Muhammadiyah Magelang \\ ${ }^{1}$ Departement Faculty of Health Science, Universitas Muhammadiyah Magelang, J1. Mayjen Bambang \\ Soegeng, Mertoyudan \\ 1email: esuhariyanti@ummgl.ac.id
}

\begin{abstract}
Abstrak
Upaya meningkatkan kesehatan masyarakat di Lingkungan Bandung, Kelurahan Sumberrejo, Kecamatan Mertoyudan, Kabupaten Magelang, dengan memanfaatkan tanaman tradisional sebagai pengobatan alami, masyarakat diajarkan untuk menanam TOGA di lahan atau pekarangan. Tujuan kegiatan ini untuk meningkatkan kesadaran dan pemahaman masyarakat mengenai pentingnya menanam TOGA di lahan atau pekarangan rumah. Metode dalam pelaksanaan kegiatan ini dimulai dengan sosialisasi, pelatihan dan pendampingan. Hasil dari kegiatan ini pengetahuan dan kesadaran mengenai pentingnya menanam TOGA meningkat. Saran bagi masyarakat di Lingkungan Bandung untuk memanfaatkan lahan kosong sebagai tempat menanam TOGA, meningkatkan pengetahuan manfaat TOGA sebagai pengobatan alami dan membudidayakan untuk menambahkan penghasilan warga. Selain itu, TOGA juga dapat dijadikan sebagai salah satu pengobatan tradisional untuk meningkatkan kesehatan masyarakat di Lingkungan Bandung, sehingga warganya tidak ketergantungan terhadap penggunaan obat-obatan medis.
\end{abstract}

Kata Kunci : Peningkatan kesehatan, TOGA, Lingkungan Bandung

\begin{abstract}
Efforts to improve public health in the Bandung environment, Sumberrejo Village, Mertoyudan District, Magelang Regency, by utilizing traditional plants as natural remedies, the community is taught to plant TOGA on land or yards. The purpose of this activity is to increase public awareness and understanding of the importance of planting TOGA in the land or yard of the house. The method in implementing this activity begins with socialization, training and mentoring. As a result of this activity, knowledge and awareness about the importance of planting TOGA increased. Suggestions for people in the Bandung environment to use vacant land as a place to plant TOGA, increase knowledge of the benefits of TOGA as a natural treatment and cultivate it to increase residents' income. In addition, TOGA can also be used as a traditional medicine to improve public health in the Bandung environment, so that its citizens are not dependent on the use of medical drugs.
\end{abstract}

Keyword : Improved health, TOGA, Lingkungan Bandung 
Volume. 2 No. 1 tahun 2020

Mei 2021 - November 2021
ISSN (online): 2722-2055 https://jurnal.umj.ac.id/index.php/ASSYIFA
AS-SYIFA: Jurnal Pengabdian dan Pemberdayaan Kesehatan Masyarakat

\section{Pendahuluan}

Swamedikasi merupakan suatu tindakan mengobati diri sendiri tanpa berkonsultasi dengan dokter. Tindakan ini dapat dilakukan dengan pengetahuan yang cukup mengenai gejala penyakit serta pengetahuan dalam khasiat suatu obat. Salah satu bentuk swamedikasi yaitu dengan memanfaatkan obat tradisional yang berkhasiat berasal dari tumbuhan (Sa'diah, Roosita and Heryanto, 2015).

WHO (World Health Organization) telah merekomendasikan penggunakan obat tradisional dalam pemeliharaan kesehatan masyarakat, pengobatan serta pencegahan penyakit kronis, penyakit degeneratif dan kanker. Indonesia telah dikenal sebagai negara yang kaya bahan alam dengan memiliki 30.000 spesies tumbuhan dari 40.000 spesies tumbuhan di dunia. Tanaman yang memiliki manfaat sebagai obat sebesar 9.600 dan \pm 300 spesies tanaman di Indonesia telah dijadikan sebagai bahan baku industri jamu dan obat tradisional, sehingga banyak masyarakat Indonesia yang menggunaan obat tradisional (Liana, 2017).

Berdasarkan data RISKESDAS (Riset Kesehatan Dasar) 2018, sebesar 48\% penduduk Indonesia telah menggunaan pengobatan ramuan jadi obat tradisional, sebesar $31,8 \%$ telah menggunakan obat tradisional ramuan sendiri, dan sebayak 31,4\% telah memanfaatkan Pelayanan Kesehatan Tradisional (YANKESTRAD) (Dewi et al., 2019).

TOGA merupakan tanaman berkhasiat yang dikelola oleh keluarga di lahan pekarangan. Tujuan penanaman ini untuk keperluan keluarga sebagai obat-obatan tradisional yang dapat dibuat secara mandiri (Mindarti and Nurbaeti, 2015). TOGA bermanfaat sebagai pengobatan dan meningkatkan kesehatan. Tanaman ini dapat ditanam sendiri di pekarangan, sehingga perlu dilakukan untuk meningkatkan masalah kesehatan. Tanaman ini juga bermanfaat sebagai sumber pendapatan masyarakat serta bermanfaat untuk memperbaiki masalah gizi keluarga (Oktaviani et al., 2020).

Lingkungan Bandung merupakan salah satu wilayah yang berada di Kelurahan Sumberrejo Kecamatan Mertoyudan Kabupaten Magelang. Wilayah ini tergolong cukup dekat dengan kota, akan tetapi sebagian besar penduduk Lingkungan Bandung bermata pencaharian sebagai petani. Tingkat kesadaran masyarakat dalam pemanfaatan lahan atau pekarangan masih terbilang cukup rendah, karena masih kurangnya pengetahuan akan pemanfaatan lahan oleh masyarakat. Lahan atau pekarangan yang luas dapat dijadikan sebagai tempat untuk menanam tanaman yang bermanfaat seperti TOGA (Tanaman Obat Keluarga). Kegiatan PPMT (Program Pemberdayaan Masyarakat Terpadu) periode II ini bertujuan untuk memberikan sosialisasi agar masyarakat memahami manfaat mengelola lahan atau pekarangan kosong dengan menanan tanaman TOGA guna meningkatkan pengetahuan masyarakat.

\section{Metode}

Dalam mencapai tujuan yang diharapkan, kegiatan PPMT periode II di Lingkungan Bandung dilakukan pemanfaatan lahan atau pekarangan kosong sebagai tempat untuk penanaman TOGA. Kegiatan tersebut dilaksanakan pada Oktober 2020 di rumah Kepala Lingkungan Bandung, dimulai dengan melakukan sosialisasi terlebih dahulu kemudian dilakukan pelatihan serta pendampingan. Media untuk sarana sosialisasi menggunakan LCD, Poster, Laptop dan PPT, sedangkan alat yang digunakan untuk pelatihan menanam TOGA menggunakan polybag, cetok, cangkul, media tanam, dan tanaman TOGA. 
ISSN (online): 2722-2055 https://jurnal.umj.ac.id/index.php/ASSYIFA
AS-SYIFA: Jurnal Pengabdian dan Pemberdayaan Kesehatan Masyarakat

Berikut merupakan alur kegiatan PPMT periode II di Lingkungan Bandung:

1. Sosialisasi TOGA

Pada kegiatan sosialisasi TOGA dilakukan dengan memaparkan materi yang dilakukan oleh salah satu mahasiswa dengan menjelaskan pentingnya menanam TOGA dan dilanjutkan dengan diskusi dan Tanya jawab

2. Pelatihan

Pada kegiatan ini masyarakat dilatih untuk menanam Tanaman TOGA seperti yang sudah dijelaskan ketika kegiatan sosialisasi, setelah dilakukan penanaman di polybag, tanaman tersebut diberikan nama dengan menggunakan papan, hal tersebut menjadikan masyarakat lebih mengenal jenis tanaman TOGA.

3. Pendampingan

Pada kegiatan ini mahasiswa serta dosen pembimbing melakukan pendampingan dengan melakukan secara langsung ditempat pelatihan penanaman TOGA dan menjelaskan manfaat tanaman, menjelaskan pasca panen tanaman dan menjelaskan bagaimana cara perawatanya.

\section{Hasil dan Pembahasan}

PPMT (Pengabdian Pada Masyarakat) Periode II ini telah dilakukan kegiatan sosialisasi Tanaman Obat Keluarga (TOGA) dengan jumlah peserta sebanyak 20 orang diikuti oleh Kader Kesehatan, Remaja Karang Taruna serta warga Lingkungan Bandung. Tujuan dari kegiatan ini untuk meningkatkan pengetahuan dan kesadaran masyarakat mengenai pentingnya menanam Tanaman Obat Keluarga (TOGA) di lahan atau pekarangan rumah. Hal ini didukung oleh penelitian Aini 2017 yang menyatakan bahwa perlu diadakan kegiatan sosialisasi yang bertujuan untuk mengubah kesadaran, pola pikir, dan gaya hidup masyarakat (Aini, 2017)

Tanaman Obat Keluarga (TOGA) bermanfaat bagi masyarakat di Lingkungan Bandung untuk meningkatkan kesehatan. Menurut penelitian Agustina (2016) penggunaan tanaman sebagai obat tradisional merupakan manifestasi dan partisipasi masyarakat dalam meningkatkan kesehatan dan diakui peranannya di berbagai Bangsa (Setiawati, Immanuel and Utami, 2016). Sehingga dengan adanya Tanaman Obat Keluarga (TOGA) di lahan atau pekarangan rumah, masyarakat dapat menggunakannya sebagai pengobatan tradisional, disamping penggunaanya yang mudah, murah, dan efek samping kecil, masyarakat dapat beralih dari pengobatan kimia ke pengobatan tradisional.

Berdasarkan hasil sosialisasi Tanaman Obat Keluarga (TOGA) dapat dilihat bahwa tingkat pemahaman dan kesadaran masyarakat mengenai manfaat dari Tanaman Obat Keluarga (TOGA) masih kurang, hanya sebagian saja yang mengetahui manfaatnya. Setelah dilakukan kegiatan sosialisasi, pemahaman dan kesadaran masyarakat di Lingkungan Bandung meningkat. Hal ini dibuktikan dengan diaadakannya Tanya jawab ketika selesai kegiatan sosialisai.

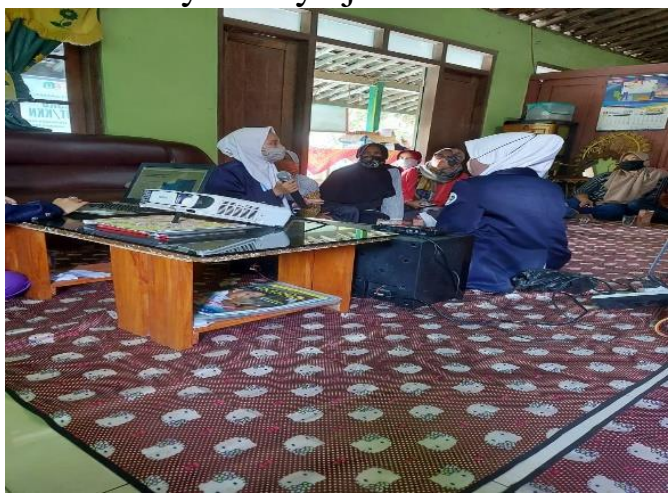

Gambar 1. Kegiatan sosialisasi TOGA 
Volume. 2 No. 1 tahun 2020 Mei 2021 - November 2021
ISSN (online): 2722-2055 https://jurnal.umj.ac.id/index.php/ASSYIFA
AS-SYIFA: Jurnal Pengabdian dan Pemberdayaan Kesehatan Masyarakat

Masyarakat di Lingkungan Bandung sebagian besar bermata pencaharian sebagai petani dan mempunyai lahan atau pekarangan yang luas, namun belum dimanfaatkan secara optimal. Sehingga dilakukan pelatihan serta pendampingan untuk menanam Tanaman Obat Keluarga (TOGA) dengan tujuan mengajarkan masyarakat menanam Tanaman Obat Keluarga (TOGA) di lahan atau pekarangan warga. Dalam penanaman tersebut telah disediakan 10 macam jenis tanaman yaitu lidah buaya, sambiloto, cincau, sereh, pandan, binahong, jeruk purut, salam, kunyit, dan sirih. Dari jenis tanaman tersebut masyarakat di Lingkungan Bandung masih belum mengetahui nama dari tanaman tersebut. Sehingga dari setiap jenis tanaman tersebut diberikan papan nama untuk memudahkan masyarakat mengenal jenis Tanaman Obat Keluarga (TOGA)
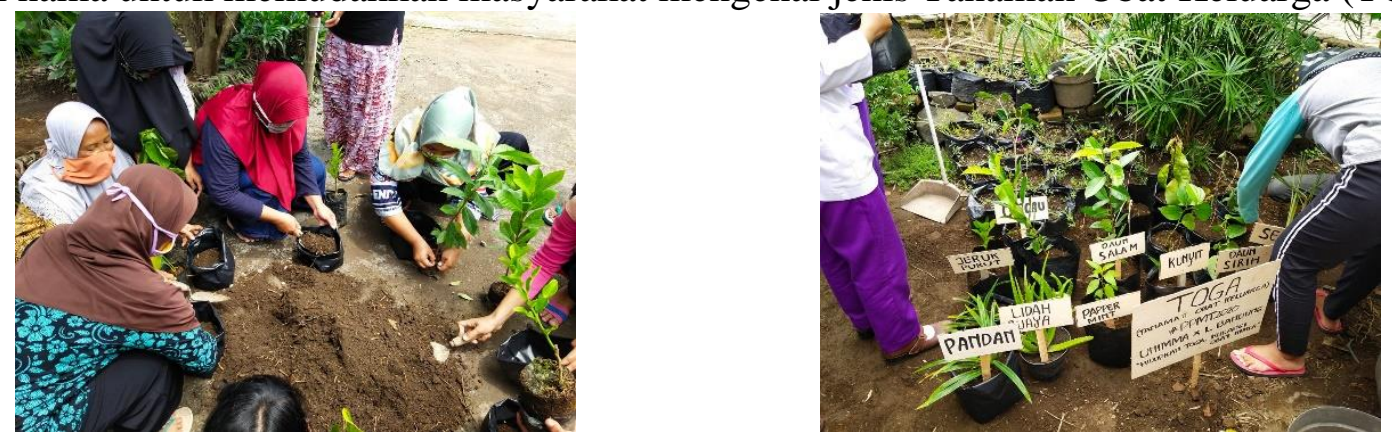

Gambar 2. Kegiatan pelatihan TOGA

Kegiatan pendampingan dilakukan oleh Dosen Pembimbing dan Mahasiswa untuk memantau secara langsung di tempat pelatihan dengan menjelaskan manfaat, perawatan, dan paca panen Tanaman Obat Keluarga (TOGA). Sehingga masyarakat menjadi lebih paham dengan pentingnya penanaman Tanaman Obat Keluarga (TOGA) di lahan atau pekarangan rumah masing-masing warga.

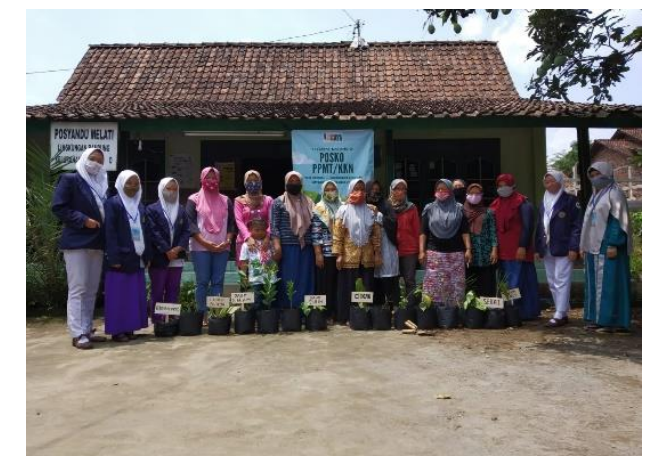

Gambar 3. Kegiatan pendampingan TOGA

Keberhasilan dari kegiatan ini dilihat dari ketercapaian target jumlah peserta, dengan $75 \%$ hadir. Pengetahuan mengenai Tanaman Obat Keluarga meningkat, dan masyarakat sangat antusias ingin menanam Tanaman Obat Keluarga (TOGA) di lahan atau pekarangan rumah masingmasing serta memanfaatkan tanaman tersebut sebagai pengobatan tradisional.

\section{Kesimpulan dan Saran}

Kegiatan sosialisasi, pelatihan serta pendampingan Tanaman Obat Tradisional (TOGA) di Lingkungan Bandung, Kelurahan Sumberrejo, Kecamatan Mertoyudan Kabupaten Magelang berjalan dengan baik dan mampu mencapai target. Kegiatan ini bertujuan meningkatkan kesadaran dan pemahaman masyarakat untuk memanfaatkan lahan atau pekarangan yang kosong 
dengan digunakan untuk menanam Tanaman Obat Keluarga (TOGA) hal ini juga bermanfaat untuk meningkatkan kesehatan masyarakat.

Berdasarkan hasil dari kegiatan PPMT Periode II yang telah dilakukan, maka telah diberikan saran sebagai berikut :

1. Masyarakat dapat mengelola lahan atau pekarangan dengan dimanfaatkan untuk menanam Tanaman Obat Keluarga (TOGA) seperti yang sudah diajarkan ketika kegiatan sosialisasi

2. Masyarakat dapat meningkatkan pengetahuan dalam memanfaatkan Tanaman Obat Keluarga (TOGA) sebagai obat tradisional, memilih menggunakan obat tradisional dibandingkan dengan obat kimia

3. Masyarakat yang memiliki lahan atau pekarangan yang luas dapat membudidayakan dan melakukan bisnis Tanaman Obat Keluarga (TOGA), sehingga masyarakat dapat menambahkan penghasilan.

\section{Ucapan Terima Kasih}

Terimakasih kepada Ibu Bidan Maymona selaku Bidan Desa dan Bapak Sahid mardiko selaku Bapak Kepala Lingkungan Bandung, yang telah memberikan ijin kepada kami sehingga kami dapat melakukan kegiatan Pengabdian Pada Masyarakat (PPMT) Periode II ini di Lingkungan Bandung.

\section{Daftar Pustaka}

Aini, N. L. (2017) 'PROSES KOMUNIKASI DALAM SOSIALISASI PEMANFAATAN TAMAN OBAT KELUARGA (TOGA) (Analisis Deskriptif Kualitatif tentang Proses Komunikasi dalam Sosialisasi Tim Penggerak PKK Desa Ngunut Mengenai Pemanfaatan TOGA kepada Masyarakat di Desa Ngunut, Kecamatan Juma'.

Dewi, R. S. et al. (2019) 'PERSEPSI MASYARAKAT MENGENAI KECAMATAN TAMPAN KOTA PEKANBARU', Jurnal Penelitian Farmasi Indonesia, 8(2).

Liana, Y. (2017) 'Analisis faktor-faktor yang mempengaruhi keluarga dalam penggunaan obat tradisional sebagai swamedikasi di Desa Tuguharum Kecamatan Madang Raya WHO ( World Health Organization ) merekomendasikan Hasil Susenas tahun 2007 menunjukan di memilih cara pengobat', 4(3), pp. 121-128.

Mindarti, S. and Nurbaeti, B. (2015) Tanaman Obat Keluarga ( TOGA ).

Oktaviani, A. D. et al. (2020) 'Pemanfaatan Lahan Pekarangan untuk Memenuhi Kebutuhan Keluarga di Desa Cintalaksana, Kecamatan Tegalwaru , Kabupaten Karawang ( Use of Yard Land to Meet Family Needs in Cintalaksana Village, Tegalwaru District, Karawang Regency )', Jurnal Pusat Inovasi Masyarakat, 2(4), pp. 535-539.

Sa'diah, S., Roosita, K. and Heryanto, R. (2015) 'Pemberdayaan Kelompok Ibu-Ibu PKK Desa Babakan, Kecamatan Darmaga , Kabupaten Bogor dalam Upaya Swamedikasi Menggunakan Tanaman Obat ( Empowerment of Mothers PKK Group at Babakan Village , Darmaga Districts , Bogor Regency , in an Swamedication Effort Us', Journal Ilmiah Pengabdian kepada Masyarakat, 1(1), pp. 62-67.

Setiawati, A., Immanuel, H. and Utami, M. T. (2016) 'The inhibition of Typhonium flagelliforme Lodd. Blume leaf extract on COX-2 expression of WiDr colon cancer cells', 
Volume. 2 No. 1 tahun 2020

Mei 2021 - November 2021
ISSN (online): 2722-2055 https://jurnal.umj.ac.id/index.php/ASSYIFA
AS-SYIFA: Jurnal Pengabdian dan

Pemberdayaan Kesehatan Masyarakat

Asian Pacific Journal of Tropical Biomedicine. Elsevier B.V., 6(3), pp. 251-255. doi: 10.1016/j.apjtb.2015.12.012. 